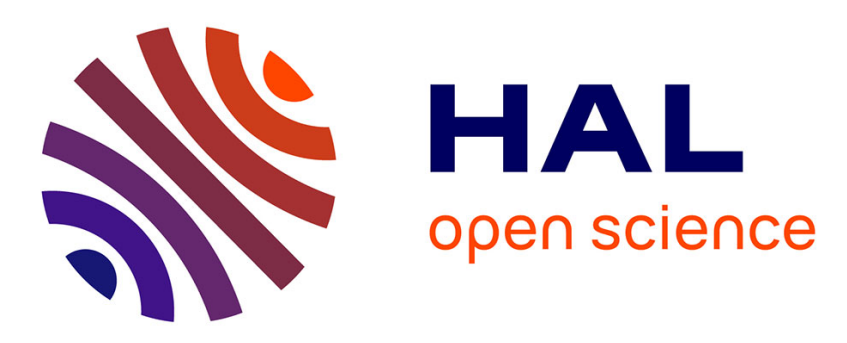

\title{
The RITS Conference: A Major Event of Biomedical Engineering in France
}

\author{
Frédérique Frouin, Véronique Migonney, Catherine Marque
}

\section{To cite this version:}

Frédérique Frouin, Véronique Migonney, Catherine Marque. The RITS Conference: A Major Event of Biomedical Engineering in France. Innovation and Research in BioMedical engineering, 2015, IRBM - Special Issue RITS 2015, 36 (6), pp.315-316. 10.1016/j.irbm.2015.11.002 inserm-01233992

\section{HAL Id: inserm-01233992 https://www.hal.inserm.fr/inserm-01233992}

Submitted on 26 Nov 2015

HAL is a multi-disciplinary open access archive for the deposit and dissemination of scientific research documents, whether they are published or not. The documents may come from teaching and research institutions in France or abroad, or from public or private research centers.
L'archive ouverte pluridisciplinaire HAL, est destinée au dépôt et à la diffusion de documents scientifiques de niveau recherche, publiés ou non, émanant des établissements d'enseignement et de recherche français ou étrangers, des laboratoires publics ou privés. 


\title{
Editorial
}

\section{The RITS conference, a major event of Biomedical Engineering in France.}

\author{
Frédérique Frouin ${ }^{1 *}$, Véronique Migonney ${ }^{2}$, Catherine Marque ${ }^{3}$ \\ 1- Inserm/CEA/Université Paris Sud/CNRS, CEA/I2BM/SHFJ, Laboratoire IMIV, Orsay, France \\ ${ }^{*}$ Corresponding author: Postal address: Laboratoire IMIV, Inserm/CEA/Université Paris Sud/CNRS, \\ CEA/I2BM/SHFJ, 4 Place du Général Leclerc, 91401 Orsay Cedex, France. E-mail address: \\ frederique.frouin@inserm.fr \\ 2- CSPBAT, UMR CNRS 7244, Université Paris 13, Sorbonne Paris Cité, Villetaneuse, France \\ 3- BMBI Laboratory, UMR CNRS 7338, Sorbonne Université-Université Technologique de Compiègne, \\ Compiègne, France
}

Research in Imaging and HealTh TechnologieS (RITS) is a French scientific meeting dedicated to Biomedical Engineering. This biennial event has given rise to four special issues of IRBM since 2009. The present issue collects some research works presented by young researchers (first author being less than 32 years old). All of them submitted a full paper (instead of a long abstract) to the meeting in order to participate in the SFGBM competition. All the published papers followed the standard reviewing process.

The 2015 RITS conference was organized by the French Society of BioMedical Engineering, the SFGBM (Société Française de Génie Biologique et Médical). It took place in Dourdan from March $25^{\text {th }}$ to March $27^{\text {th }}$. To address the necessity to work in an open scientific environment, the SFGBM invited some French scientific societies to co-organize special sessions and had the great pleasure to welcome the French Society of Biomechanics (SB) and the French Society of Nuclear Medicine (SFMN). In addition, the conference was associated with a colloquium dedicated to the projects that have been selected in 2011 by the TecSan ANR committee, TecSan being a program dedicated to health technologies. This was the opportunity to make the assessment of the funded projects public, and this meeting completed the special issue dedicated to this program that was recently published in IRBM [1].

This new edition of RITS was a large success with more than 150 participants. For the opening of the conference, Professor Catherine Marque gave a fascinating talk dedicated to one major (but still unknown) event in our life: childbirth. She gave a comprehensive review of her research works dedicated to the investigation and the modeling of labor, and we can refer interested readers to her recent works [2-7] for further details.

During these three days, five special sessions were also organized: 1) Nanomedicine (organizer: Marc Lamy de la Chapelle, guest speaker: Igor Chourpa); 2) Genetic Imaging (organizer: Vincent Frouin, guest speaker: Roberto Toro); 3) Genotypic and Phenotypic Imaging (organizers: Laurence Bordenave and Elif Hindie from the SFMN, guest speakers: Caroline Rousseau, Philippe Fernandez, and David Taïeb); 4) Biomechanics and Medical Imaging (organizers: Frédéric Marin and Jacques Ohayon from the SB, guest speakers: Jacques Ohayon, Yohan Payan, Stéphane Avril, Frédéric Marin, Patrick Clarysse and Wafa Skalli ); 5) Imaging and Therapy using Ultrasound (organizer: Ayache Bouakaz, guest speaker: François Tranquart).

Of course conventional oral and poster scientific sessions were also defined. The repartition between oral and poster was done according multiple criteria, including referee advice, homogeneity of sessions to favor fruitful discussions, equilibrium between the different research fields. To highlight poster presentation, a short oral talk (two minutes long) was given by poster presenters at the beginning of each session. Following the acceptance of authors, most of the presented communications have been made available at http://www.hal.inserm.fr/RITS2015.

As stated before, the RITS conference was also the occasion to give SFGBM awards to young researchers. The SFGBM jury attributes three prizes, shared equally, to Wojciech Kwiecinski (oral 
presentation) [8], Mahmoud Hassan (oral presentation) [9] and Sophie Collin (poster presentation) [10].

Another key point of the conference was the "Prix de Thèse en Génie Biologique et Médical" that are the annual awards for the best PhDs in Biomedical Engineering. This 2015 edition was open to candidates having defended their PhD in 2014. The prizes were sponsored by the SFGBM, the IEEE EMBS France chapter, and the AGBM (Association pour le Génie Biologique et Médical). The Research Award was attributed to Doctor Hanna Becker, while accessit was attributed to Doctor Helena Felgueiras. The Innovation Award, for encouraging technology transfer of innovative medical technologies to industry, was attributed to Doctor Clement Papadacci while accessit was attributed to Doctor Guillaume Kazmitcheff.

Finally, Professor Christian Roux received the Claude Fourcade Award (the SFGBM senior distinction) in recognition for his high contribution to Biomedical Engineering and his exceptional commitment, at national and international levels.

On behalf of the organization and scientific committees, we would like to thank all the committee members, all the reviewers and all the participants who actually contributed to the success of the 2015 RITS conference.

\section{References}

1- Frouin F, Tassy D, Vasmant D. An Overview of ANR TecSan Projects in 2011, IRBM, 2015, 36 (2): 61. DOI: $10.1016 /$ j.irbm.2015.02.001

2- Alexandersson A, Steingrimsdottir T, Terrien J, Marque C, Karlsson B The Icelandic 16-electrode electrohysterogram database. Scientific data, 2015, 2:150017. DOI:10.1038/sdata.2015.17

3- Alamedine D, Diab A, Muszynski C, Karlsson B, Khalil M, Marque C. Selection algorithm for parameters to characterize uterine EHG signals for the detection of preterm labor. Signal Image and Video Processing, 2014, 8(6):1169-1178. DOI: 10.1007/s11760-014-0655-2

4- Diab A, Hassan M, Marque C, Karlsson, B. Performance analysis of four nonlinearity analysis methods using a model with variable complexity and application to uterine EMG signals. Medical Engineering \& Physics, 2014, 36(6):761-767. DOI: 10.1016/j.medengphy.2014.01.009

5- Mischi M, Karlsson B, Signorini MG, Ungureanu M, Marque C. Pregnancy monitoring. Computational and mathematical methods in medicine, 2014, 2014:507613.

DOI:10.1155/2014/507613

6- Hassan M, Terrien J, Muszynski C, Alexandersson A, Marque C, Karlsson B. Better Pregnancy Monitoring Using Nonlinear Correlation Analysis of External Uterine Electromyography IEEE Transactions on Biomedical Engineering, 2013, 60(4): 1160-1166. DOI: 10.1109/TBME.2012.2229279

7- Laforet J, Rabotti C, Mischi M, Marque C. Improved multi-scale modeling of uterine electrical activity. IRBM, 2013, 34 (1): 38-42 . DOI: 10.1016/j.irbm.2012.12.004

8- Kwiecinski W, Provost J, Dubois R, Sacher F, Haïssaguerre M, Legros M, Nguyen-Dinh M, Dufait R, Tanter $M$, Pernot $M$ Validation of an intracardiac ultrasonic therapy-imaging dual mode transducer IRBM, 2015, 36 (6): 351-354. doi:10.1016/j.irbm.2015.04.002

9- Hassan $M$, Wendling $F$. Tracking dynamics of functional brain networks using dense EEG, IRBM, 2015, 36 (6):.324-328. doi:10.1016/j.irbm.2015.09.004

10- Collin S, Anselmi A, Verhoye JP, Haigron P, Flechera, E. Virtual positioning of ventricular assist device for implantation planning, IRBM 2015, 36 (6): 317-323. doi:10.1016/j.irbm.2015.09.005 
